\title{
Microbiological properties of Turkish Beyaz cheese samples produced with different probiotic cultures
}

\author{
Filiz Yangılar ${ }^{1 *}$ and Salih Özdemir ${ }^{2}$ \\ ${ }^{1}$ Department of Food, Engineering Faculty, Ardahan University, Ardahan, Turkey. \\ ${ }^{2}$ Department of Agricultural, Food Engineering, Atatürk University, Erzurum, Turkey.
}

Accepted 26 April, 2013

\begin{abstract}
In this study, Turkish Beyaz cheese samples were produced by adding commercial lactic culture [Lactococcus lactis and Lactococcus cremoris $(A)$ ] and different probiotics [Bifidobacterium bifidum BB-12 (B), Bifidobacterium bifidum BB-12+Lactobacillus acidophilus LA-5 (C), Bifidobacterium bifidum (D) and Bifidobacterium longum (E)]. Probiotic cultures were added to cheese milk at least $10^{7} \mathrm{cfu} / \mathrm{ml}$ levels. Some microbiological properties of this cheese samples were investigated during ripening periods of 2, 15, 30 and 60 days. As a result, at beginning of the ripening period, the yeast-mould and coliform bacteria counts of all Beyaz cheese samples were higher than the standard values but the counts decreased during ripening period and reached standard values. It was determined that lactic acid bacteria counts (MRS agar) of probiotic cheese samples were lower than the control cheese. While the lactic acid bacteria counts growth on M17 agar of the cheese samples produced with C culture were the highest, the lactic acid bacteria counts of cheese produced with E culture were determined as the lowest. In addition, the probiotic bacteria counts of experimental cheeses decreased during the ripening period. The number of Lactobacillus acidophilus $L A-5$ in cheese $C$ showed a decrease of 3 logarithmic units at the end of the ripening period.
\end{abstract}

Key words: White cheese, probiotic culture, survival, Bifidobacterium bifidum, Bifidobacterium longum.

\section{INTRODUCTION}

Probiotics are live microbial food supplements, which are beneficial for the health of consumers by maintaining, or improving their intestinal microbial balance (Fuller, 1989; Mattila-Sandholm et al., 2002). There are different studies on human beings that provide evidence about health effects of probiotics. Foods containing probiotic bacteria belong to the category of functional foods, which are claimed to have several health specific benefits (Gupta and Abu-Ghannam, 2012; Pitino et al., 2012). Various parameters must be considered when adding probiotic bacteria. Probiotics can be described as dietetic and therapeutic products obtained by fermentation. A number of therapeutic benefits have been attributed including control of diarrhea, improvement in lactose utilization in lactose malabsorbers, and improvement in host immune responses (Tharmaraj and Shah, 2004). products obtained by fermentation. A number of therapeutic benefits have been attributed including control of diarrhea, improvement in lactose utilization in lactose malabsorbers, and improvement in host immune responses (Tharmaraj and Shah, 2004). Probiotic organisms to be beneficial in food systems, cultures should maintain viability in the food until the time of consumption and be present in significant numbers, at levels of $10^{7}$ viable cells per $\mathrm{g}^{-1}$ or $\mathrm{mL}^{-1}$ of a product (Ishibashi and Shimamura, 1993). Milk, yoghurt, fermented 
milk, desserts, fruit juice and various kinds of cheese are among the major recent probiotic products (Souza and Saad, 2009). A variety of probiotic dairy products, including cheeses with particular functional properties, is available in market worldwide (Gomes et al., 1995; Gardiner et al., 1998; Songisepp et al., 2004; Ross et al., 2005; Ibrahim et al., 2010; Songisepp et al., 2012). Especially, among different food products able to deliver probiotics, cheese has been claimed as a good carrier of probiotic bacteria because it enables their passage as viable cells throughout the gastrointestinal tract (Kılıç et al., 2009; Madureira et al., 2008; Rodrigues et al., 2012). As pointed out by Cruz et al. (2009), cheese is one of the most versatile food products, offering opportunities for many marketing strategies, new technology developments, and for adding health benefits, including the possibility of transforming it into a probiotic food carrier (dos Santos et al., 2012). Cheese contains a complex combination of microorganisms that changes with time; initially containing large numbers of starter lactic acid bacteria (SLAB) and then with maturation, an increasing number of nonstarter lactic acid bacteria (NSLAB) (Darukaradhya et al., 2006). To enumerate probiotic bacteria in such a mixed population, selective media should be employed that would allow the growth of the organisms of interest and inhibit other microorganisms encountered in a particular food product. Alternatively, differential media that will allow easy identification of probiotic colonies in the presence of other colonies can be used, provided the probiotic bacteria are in sufficient numbers. In the absence of standard selective or differential media, reliable enumeration of probiotic bacteria in the less complex microbial populations found in yoghurt has been reported to be difficult (Talwalkar and Kailasapathy, 2004). Turkish Beyaz cheese is most widely consumed in Turkey. Turkish Beyaz cheese is a soft or semi-hard type cheese which is produced from sheep's or cow's milk or their mixture (Kılıç et al., 2009). Previous studies have shown that there are significant strain differences in the viability of probiotic bacteria during storage of cultured dairy products (Ross et al., 2002). An adequate strain selection must be carried out to produce probiotic dairy products (Vinderola and Reinheimer, 2003). In addition to good viability in the intestine, technological properties are a prerequisite for potential use of the strains as probiotic culture in cheese (Kask et al., 2003). Most studies on probiotic cheeses have focused on maintaining a high probiotic population during the shelf life of the food. Results have shown that several cheese varieties, example, Cheddar, Gouda, Canestrato Pugliese, Fresco, etc., are able to carry high numbers of different strains of probiotic bacteria for variable periods (Phillips et al., 2006; Roy et al., 1998; Vinderola et al., 2000).

This study was to evaluate success in maintaining the viability of different probiotic strains (Bifidobacterium bifidum BB - 12, Bifidobacterium bifidum BB - 12+ Lactobacillus acidophilus LA-5, Bifidobacterium bifidum and Bifidobacterium longum) in Turkish Beyaz cheese samples.

\section{MATERIALS AND METHODS}

\section{Cultures}

Freeze-dried cultures of Lactococcus lactis subsp. lactis and Lactococcus lactis subsp. cremoris obtained from DSM Food Specialties Pty. Ltd. (Moorebank, NSW, Australia) were used for cheese starter culture preparation. Besides, the different strains of probiotic bacteri were used as adjunt cultures: this cultures, $B$. bifidum $B B-12$ and $B$. bifidum $B B-12+L$. acidophilus $L A-5$ were obtained from Peyma Hansen (Gayrettepe, Istanbul, Turkey) while $B$. bifidum and $B$. longum were obtained from Christian Hansen (Christian Hansen, Valinnhos, Brazil). The organism were activated with the methods in the study of Martensson et al. (2002).

\section{Cheese Producing}

In this study, five groups of Turkish Beyaz cheeses were produced. A control batch was produced using $1 \mathrm{~mL} / 100 \mathrm{~mL}$ commercial culture mix consisting of Lactococcus lactis and Lactococcus cremoris and four batch [B (Bifidobacterium bifidum BB-12), C (Bifidobacterium bifidum BB-12+Lactobacillus acidophilus LA-5), D (Bifidobacterium bifidum) and E (Bifidobacterium longum)] was produced using equal concentrations of the probiotic and commercial mixes. Cheese producing trials were performed initially with $100 \mathrm{~L}$ of raw milk. The milk was pasteurized at $65^{\circ} \mathrm{C}$ for $30 \mathrm{~min}$ and cooled to $35^{\circ} \mathrm{C}$, and $\mathrm{CaCl}_{2}(20 \mathrm{~g} / 100 \mathrm{~L})$ was added into the milk. A commercial culture mix inoculum $(1 \mathrm{~mL} / 100 \mathrm{~mL})$ of the cheese starters (Lactococcus lactis and Lactococcus cremoris) was added to each of the vats. Probiotic strains were inoculated into samples (B, C, D and E) at levels high enough to attain $10^{7} \mathrm{cfu} / \mathrm{mL}$ in cheese milk. A $12 \mathrm{ml}$ of chymosin (Peyma Hansen, Turkey) dispersed in $100 \mathrm{~mL}$ water was added to each cheese vat at a level sufficient to coagulate the milk in 90 min. After curdling, the curds were cut into small cubes, approximately $1 \mathrm{~cm}^{3}$ and the curds were allowed to rest. After pressed, the cheeses were cut into cubes about $8 \times 8 \mathrm{~cm}$ and the cubes salted with pasteurized brine $(12 \% \mathrm{w} / \mathrm{v}, \mathrm{NaCl})$ for 6 $\mathrm{h}$. Then brine-salting, cheese was held at room temperature for 12 $\mathrm{h}$ and cheese blocks were then packed in bags containing brine and all cheese was ripened at $4 \pm 1^{\circ} \mathrm{C}$ for 60 days. The cheese production was performed in triplicate (Demirci and Şimşek, 1997). Cheese samples were analysed in 2, 15, 30 and 60 days of storage.

\section{Microbiological analysis methods}

A pour plate method was employed for the determination of microbial groups. Eleven gram of samples cheese were homogenized in $99 \mathrm{ml}$ of a sterile solution $(0.85 \% \mathrm{NaCl})$ using a Stomacher (Lab. Stomacher Blander 400 BA 7021, Swardmedical). Further decimal dilutions were prepared with the same diluent (Diliello, 1982). Analyses were carried out using the following procedures:

1. Total aerobic mesophilic bacteria were enumerated on plate count agar (Oxoid) and with aerobic incubation at $30 \pm 1^{\circ} \mathrm{C}$ for $48 \mathrm{~h}$ (Diliello, 1982).

2. Coliform counts were determined by the Violet Red Bile Agar (Oxoid) with plate incubation at $35 \pm 2^{\circ} \mathrm{C}$ for $48 \mathrm{~h}$ (Diliello, 1982).

3. LAB counts were determined by MRS-agar (Oxoid) and incubated anaerobically at $30^{\circ} \mathrm{C}$ for $48 \mathrm{~h}$ (Diliello, 1982). 
Table 1. Counts of the microbial groups found in probiotic Beyaz cheese samples (log cfu/g).

\begin{tabular}{|c|c|c|c|c|c|c|}
\hline $\begin{array}{l}\text { Beyaz Cheese } \\
\text { Samples }\end{array}$ & $\begin{array}{c}\text { Ripening } \\
\text { Period (day) }\end{array}$ & TAMB & $\begin{array}{l}\text { LAB grown on } \\
\text { MRS Agar }\end{array}$ & $\begin{array}{l}\text { LAB grown on } \\
\text { M17 Agar }\end{array}$ & $\begin{array}{c}\text { Coliform Group } \\
\text { Bacteria }\end{array}$ & $\begin{array}{c}\text { Yeast and } \\
\text { Mould }\end{array}$ \\
\hline \multirow{4}{*}{ A (Control) } & 2 & $7.63 \pm 0.56$ & $7.15 \pm 0.59$ & $6.82 \pm 0.32$ & $3.80 \pm 0.31$ & $2.01 \pm 0.43$ \\
\hline & 15 & $7.07 \pm 0.63$ & $7.39 \pm 0.70$ & $7.10 \pm 0.68$ & $2.63 \pm 0.29$ & $1.34 \pm 0.12$ \\
\hline & 30 & $6.72 \pm 0.26$ & $6.90 \pm 0.41$ & $6.55 \pm 0.71$ & $1.05 \pm 0.12$ & $<1$ \\
\hline & 60 & $7.13 \pm 0.37$ & $7.73 \pm 0.52$ & $6.23 \pm 0.50$ & $<1$ & $<1$ \\
\hline \multirow{4}{*}{ B } & 2 & $8.36 \pm 0.21$ & $7.84 \pm 0.46$ & $6.26 \pm 0.46$ & $2.56 \pm 0.56$ & $2.70 \pm 0.09$ \\
\hline & 15 & $7.17 \pm 0.32$ & $7.27 \pm 0.34$ & $7.34 \pm 0.23$ & $3.83 \pm 0.41$ & $2.07 \pm 0.22$ \\
\hline & 30 & $7.74 \pm 0.74$ & $6.79 \pm 0.26$ & $6.04 \pm 0.18$ & $2.35 \pm 0.20$ & $<1$ \\
\hline & 60 & $6.82 \pm 0.61$ & $5.71 \pm 0.35$ & $5.51 \pm 0.39$ & $<1$ & $<1$ \\
\hline \multirow{4}{*}{ C } & 2 & $8.27 \pm 0.35$ & $8.07 \pm 0.43$ & $7.34 \pm 0.60$ & $1.44 \pm 0.16$ & $2.72 \pm 0.32$ \\
\hline & 15 & $8.18 \pm 0.29$ & $7.20 \pm 0.64$ & $8.43 \pm 0.77$ & $2.56 \pm 0.21$ & $1.17 \pm 0.15$ \\
\hline & 30 & $7.63 \pm 0.32$ & $7.57 \pm 0.56$ & $7.20 \pm 0.35$ & $2.25 \pm 0.10$ & $2.30 \pm 0.10$ \\
\hline & 60 & $6.75 \pm 0.47$ & $6.18 \pm 0.34$ & $5.34 \pm 0.41$ & $1.03 \pm 0.16$ & $2.02 \pm 0.24$ \\
\hline \multirow{4}{*}{ D } & 2 & $7.61 \pm 0.24$ & $6.15 \pm 0.17$ & $6.83 \pm 0.38$ & $3.87 \pm 0.39$ & $2.03 \pm 0.12$ \\
\hline & 15 & $7.87 \pm 0.50$ & $7.17 \pm 0.43$ & $7.63 \pm 0.20$ & $1.65 \pm 0.21$ & $2.37 \pm 0.30$ \\
\hline & 30 & $6.72 \pm 0.38$ & $6.73 \pm 0.25$ & $6.03 \pm 0.49$ & $1.37 \pm 0.13$ & $<1$ \\
\hline & 60 & $7.17 \pm 0.42$ & $7.66 \pm 0.39$ & $7.23 \pm 0.41$ & $<1$ & $<1$ \\
\hline \multirow{4}{*}{$\mathrm{E}$} & 2 & $7.40 \pm 0.63$ & $7.19 \pm 0.31$ & $6.90 \pm 0.38$ & $2.85 \pm 0.34$ & $2.01 \pm 0.32$ \\
\hline & 15 & $6.88 \pm 0.28$ & $6.14 \pm 0.47$ & $6.24 \pm 0.67$ & $1.73 \pm 0.18$ & $2.31 \pm 0.24$ \\
\hline & 30 & $7.14 \pm 0.37$ & $7.02 \pm 0.40$ & $5.60 \pm 0.52$ & $1.26 \pm 0.10$ & $<1$ \\
\hline & 60 & $6.70 \pm 0.45$ & $6.85 \pm 0.53$ & $6.01 \pm 0.70$ & $<1$ & $<1$ \\
\hline
\end{tabular}

** The values presented are the average of three recurrences

A(Control): Only lactic culture; B: $B$. bifidum BB-12+lactic culture; C: $B$. bifidum $B B-12+L$. acidophilus $L A-5+$ lactic culture

D: B. bifidum+lactic culture; E: B. longum+lactic culture; TAMB: Total aerobic meshophylic bacteria; LAB: Lactic acid bacteria

4. LAB counts were determined by M17-agar (Oxoid) and incubated aerobically at $30 \pm 1^{\circ} \mathrm{C}$ for $48 \mathrm{~h}$ (Diliello, 1982).

5. Yeasts and moulds were enumerated on Potato Dextrose Agar (PDA) (Oxoid) and incubated at $25^{\circ} \mathrm{C}$ for 5 - 7 days (Koburger and Marth, 1984).

6. Probiotics strains, the count of $L$. acidophilus $L A-5$, was enumareted on MRS-D-Sorbitol agar and for the count of Bifidobacterium strains were enumareted on MRS-NNLP agars and incubated aerobically at $37^{\circ} \mathrm{C}$ for $72 \mathrm{~h}$ (Dave and Shah, 1997).

\section{Statistical analysis}

All statistical analysis was performed on a computer running SAS for windows. Analysis of variance was performed using the routine Proc ANOVA. Significant treatment was separated using Duncan's multiple range test (Yıldız and Bircan, 1994).

\section{RESULTS AND DISCUSSION}

Results of some microbiological analysis of Beyaz cheese samples during ripening are given in Table 1.

The TAMB counts of samples were around $6.70 \mathrm{cfu} / \mathrm{g}$ and $8.36 \mathrm{cfu} / \mathrm{g}$. Generally, as the ripening periods increased, the acidity had an inhibiting effect on the total number of microorganisms and therefore, the TAMB counts of samples decreased. In addition, the studies presented that the quality of the raw material, the conditions under which cheese is produced and ripened, the thermal operations applied and the cultures added had an effect on the TAMB numbers of sample white cheese (Fontecha et al., 1990).

Similarly Nikolaou et al. (2002) found that the TAMB counts of low-fat Batzos cheese decreased at the end of the ripening period. The penetration of salt into cheese generally decrease the bacteria counts. The lactic acid bacteria counts on MRS agar in Beyaz cheese samples added probiotic bacteria were lower than that of unadded. As ripening periods increased, LAB count of samples decreased. This can stem from increasing of salt ratio during ripening. Laleye et al. (1987) reported that the increasing of salt ratio in cheese decreased the lactic acid bacteria numbers. Same result was found by Sousa and Macata (1996). The lactic acid bacteria counts on M17 agar of cheese samples increased at 15 days of ripening, but counts decreased at 30 and 60 days of ripening. Thus, throughout ripening, $B$. lactis $B b-12$ was present in high numbers and the most predominanat flroa in Beyaz cheese (Brearty et al., 2001). Kılıç et al. (2009) reported that lactic acid bacteria counts on M17 agar of the Beyaz cheese samples were 8 logcfu/g at the 


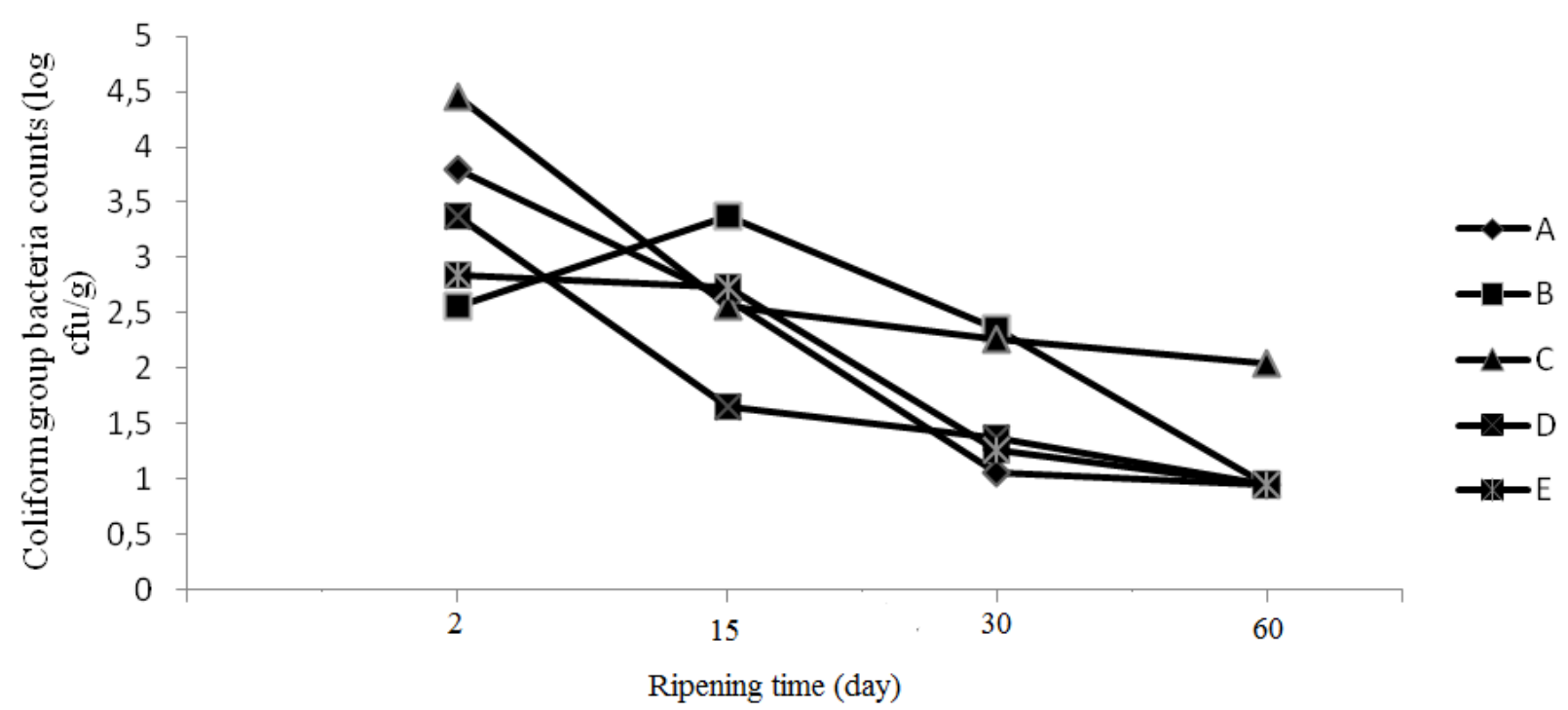

Figure 1. The changes of coliform bacteria counts of probiotic Beyaz cheese samples during ripening

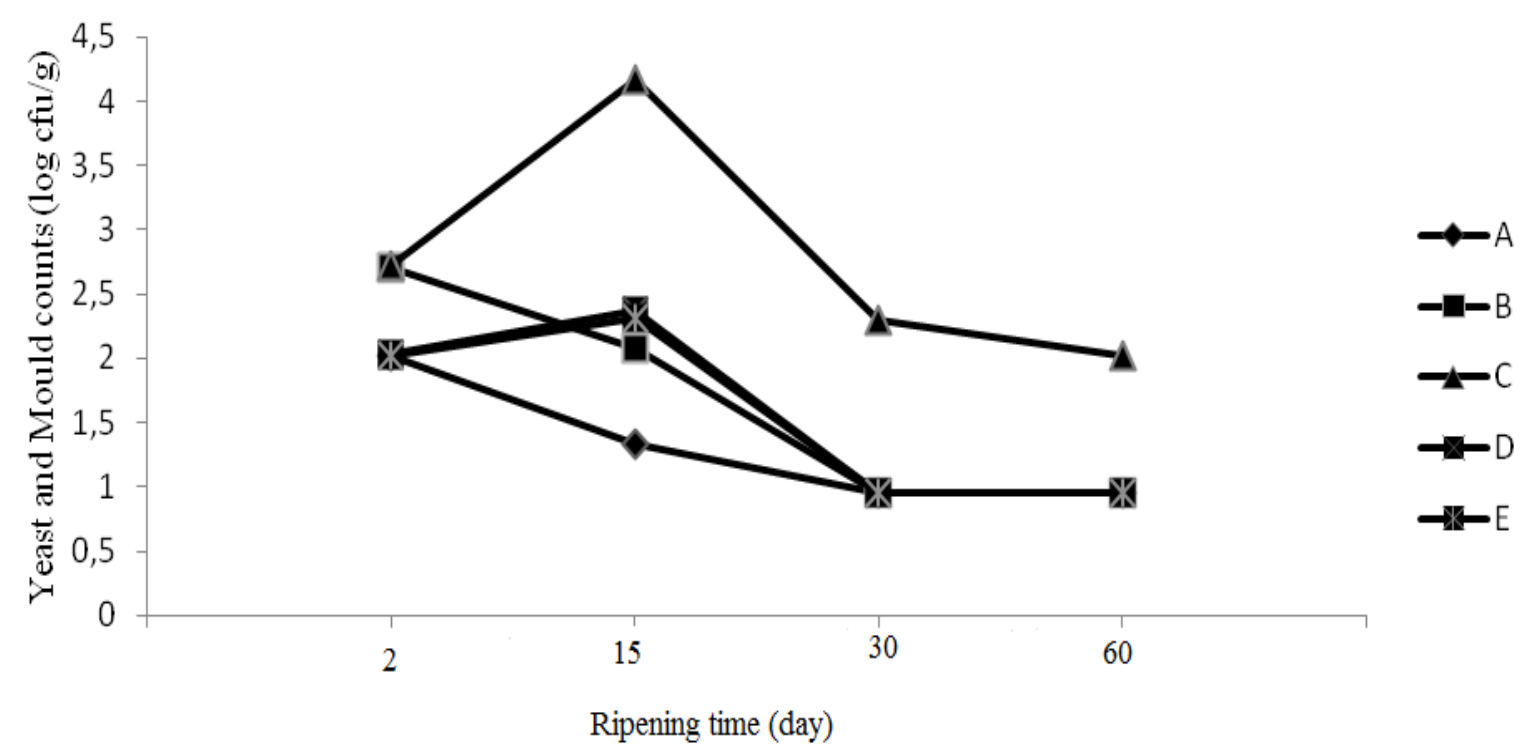

Figure 2. The changes of of yeast and mould counts of probiotic Beyaz cheese samples during ripening.

beginning of ripening period and at ripening period for 120 days cheese samples had 5 logcfu/g lactic acid bacteria counts. Breatry et al. (2001) found similiar results in Cheddar cheese samples. These findings were parallel to our findings.

The coliform group bacteria counts of samples were found around $<1$ and 3.87 logcfu/g. At Turkish Beyaz Cheese standard, the coliform counts were limited to maximum 2 logcfu/g (TS591). During ripening of Beyaz cheese samples, coliform counts decreased (Figure 1). The coliform counts of all samples ripened for 60 days were under standard value (TS591). Kılıç et al. (2009) reported the coliform counts of probiotic Beyaz cheese samples were lower than standard value (<2log cfu/g). The lowest yeast and mould count was found in samples added only lactic starters. At 15 days of ripening period, yeast and mould counts increased (Figure 2). Then, the counts decreased at 30 and 60 days of ripening. Guizani et al. (2006) reported that yeast and mould can be found in cheese at all ripening periods. This state can result from the fact that yeast and moulds can grow at different water activity (aw:0.65-0.90), low $\mathrm{pH}$ (min.3) and different temperature degrees (Montville and Matthews, 2005).

The probiotic bacteria counts used in the production of Beyaz cheese samples during ripening are given in Table 2.

As seen from Table 2, all probiotic bacteria counts 
Table 2. The probiotic bacteria counts of Beyaz cheese samples (logcfu/g).

\begin{tabular}{|c|c|c|c|}
\hline \multirow{2}{*}{ Beyaz cheese sample } & \multirow{2}{*}{$\begin{array}{c}\text { Ripening period (day) } \\
2\end{array}$} & \multicolumn{2}{|c|}{ Probiotic bacteria counts (log cfu/g) } \\
\hline & & $7.61 \pm 0.20$ & \\
\hline \multirow{3}{*}{ B (B. bifidum BB12) } & 15 & $7.34 \pm 0.35$ & \\
\hline & 30 & $6.87 \pm 0.12$ & \\
\hline & 60 & $6.50 \pm 0.18$ & \\
\hline \multirow{4}{*}{ C ( B. bifidum BB12* ${ }^{*}$ L. acidophilus $\left.L A-5^{* *}\right)$} & 2 & $7.80 \pm 0.42\left(^{*}\right)$ & $\left.8.61 \pm 0.21{ }^{* *}\right)$ \\
\hline & 15 & $6.74 \pm 0.16$ & $7.60 \pm 0.32$ \\
\hline & 30 & $6.78 \pm 0.12$ & $6.41 \pm 0.14$ \\
\hline & 60 & $6.33 \pm 0.33$ & $5.13 \pm 0.12$ \\
\hline \multirow{4}{*}{ D (B. bifidum) } & 2 & $7.90 \pm 0.41$ & \\
\hline & 15 & $7.80 \pm 0.26$ & \\
\hline & 30 & $6.79 \pm 0.34$ & \\
\hline & 60 & $6.67 \pm 0.37$ & \\
\hline \multirow{4}{*}{$\mathrm{E}$ ( B. longum) } & 2 & $6.72 \pm 0.50$ & \\
\hline & 15 & $5.64 \pm 0.31$ & \\
\hline & 30 & $6.52 \pm 0.10$ & \\
\hline & 60 & $5.20 \pm 0.27$ & \\
\hline
\end{tabular}

** The values presented are the average of three recurrences

${ }^{*} B$. bifidum $B B 12 ;{ }^{* *} L$. acidophilus $L A-5$

decreased during ripening periods. But, ripening temperature also had an affect on the counts of probiotic in all cheeses. Although B. bifidum BB12 decreased at 1 log level, $L$. acidophilus $L A-5$ decreased at 3 log levels. Different probiotic bacteria can be tolered at different level of acidity and salt. Ozer et al. (2009) made probiotic Beyaz cheese with $B$. bifidum BB12 and $L$. acidophilus and found that the probiotic bacteria decreased during ripening periods for 90 days at significant level. The result was parallel with our research results. But, Fritzen-Freire (2010) reported that counts of $B$. Bifidum $B B 12$ in cheese did not decrease during ripening periods for 28 days. The limiting factor on the growth of $B$. Bifidum is soluble oxygen and salt. Gomes et al. (1995) found that there was an initial increase in $L$. acidophilus during production but then there was a 2 log decrease in 9 weeks. Bergamini et al. (2006) found that $L$. acidophilus counts in cheese samples increased during ripening periods for 60 days. But, Philips et al. (2006) found that $L$. acidophilus in Cheddar cheese decreased to $3 \log \mathrm{cfu} / \mathrm{g}$ at during 7 mounths of ripening.

\section{Conclusions}

The aim of this study was to investigate microbiological properties of Turkish Beyaz cheese which was probiotic cultures (Bifidobacterium bifidum BB-12, Bifidobacterium bifidum BB-12+ Lactobacillus acidophilus $L A-5$, Bifidobacterium bifidum and Bifidobacterium longum) and determine the viability of the probiotic strains. At the beginning of the ripening period, the yeast-mould and coliform bacteria counts of all Beyaz cheese samples were higher than the standard values but the counts decreased during ripening period and were within the admissible range according to Turkish Standards for cheese (TS 591, 1995). All probiotic strains survived the cheese making process at a high level without any alteration of cheese production process. At the end of 2 months ripening at $4^{\circ} \mathrm{C}$, these cultures maintained the levels of $>6.0$ log cfu $\mathrm{g}^{-1}$. In addition, the probiotic bacteria counts of experimental cheeses decreased during the ripening periods. While the population of Bifidobacterium species was reduced by 1 log, the number of Lactobacillus acidophilus $L A-5$ reducted by $3 \log$ at the end of the ripening period, respectively. The results show that the probiotic culture strains can be used in Turkish Beyaz cheese production alone or in combination with commercial starter cultures successfully.

\section{ACKNOWLEDGEMENTS}

This work was supported financially by the Ataturk University Research fund (Project No: 2008/64).

\section{REFERENCES}

Bergamini CV, Hynes ER, Zalazar CA (2006). Influence of probiotic bacteria on the proteolysis profiles of a semi- hard cheese. Int. Dairy J. 16(8):856-866.

Brearty SM, Ross RP, Fitzgerald GF, Collins JK, Wallace JM, Stanton C (2001). Influence of two commercially available bifidobacteria cultures on Cheddar cheese quality. Int. Dairy J. 11:599-610.

Cruz AG, Buriti FCA, Souza CHB, Faria JAF, Saad SMI (2009). Probiotic cheese: health benefits, technological and stability aspects. Trends Food Sci and Technol. 20: 344-354. 
Dave RI, Shah NP (1997). Viability of yoghurt and probiotic bacteria in yoghurt made from commercial starter cultures. Int. Dairy J. 7(1):3141.

Darukaradhya J, Philips M, Kailasapathy K (2006). Selective enumeration of Lactobacillus acidophilus, Bifidobacterium spp., starter lactic acid bacteria and non-starter lactic acid bacteria from Cheddar cheese.

Int. Dairy J. 16:439-445.

Demirci M, Şimşek O (1997). Süt işleme teknolojisi. Hasad Yayıncılık Ltd. Şti., İstanbul.

Diliello LR (1982). Methods in food and dairy microbiology. Avi. Publishing Company Inc., USA, p. 142.

dos Santos KMO, Bomfim MAD, Vieira ADS, Benevides SD, Saad SMI, Buriti FCA, Egito AS (2012). Probiotic caprine Coalho cheese naturally enriched in conjugated linoleic acid as a vehicle for Lactobacillus acidophilus and beneficial fatty acids. Int. Dairy J. 24:107-112.

Fontecha J, Pebez M, Juarez M, Reguena T, Gomez C, Ramos M (1990). Biochemical and microbiological characteristics of artisanal hard goat's cheese. J. Dairy Sci. 73:1150-1157.

Fritzen-Freire CB, Müler CMO, Laurindo JB, Prudencio ES (2010). The influence of Bifidobacterium bifidum $B B-12$ and lactic acid incorporation on the properties of Minas Frescal cheese. J. Food Eng. 96:621-627.

Fuller R (1989). Probiotics in man and animals. J. App. Bacteriol. 66:365-378

Gardiner G, Ross RP, Collins JK, Fitzgerald G, Stanton C (1998). Develpoment of a probiotic cheddar cheese containing humanderived Lactobacillus paracasei strains. Appl. Environ. Microbiol. 64:2192-2199.

Gomes A, Malcata F, Klaver, F, Grande H (1995). Incorporation and strain Ki in a cheese product. Net. Milk Dairy J. 49:71-95.

Guizani N, Attabi ZA, Kasapis S, Gaafar OM (2006). Ripening profiles of semi-hard standard goat cheese made from pasteurized milk. Int. J. Food Prop. 9(3): 523-532.

Gupta S, Abu-Ghannam N (2012). Probiotic fermentation of plant based products: possibilities and opportunities. Crit. Rev. Food Sci. Nutr. 52:183-199.

Ishibashi N, Shimamura S (1993). Bifidobacteria research and development in Japan. Food Tech. 47:126-135.

Ibrahim F, Ruvio S, Granlund L, Salminen S, Viitanen M, Ouwehand AC (2010). Probiotics and immunosenescence: Cheese as a carrier. FEMS Immunol. Med. Microbiol. 59:53-59.

Kask S, Adamberg K, Orlowski A, Vogensen FK, Moller PL, Ardö Y, Paalme T (2003). Physiological properties of Lactobacillus paracasei, $L$. danicus and $L$. curvatus strains isolated from Estonian semi-hard cheese. Food Res. Int. 36:1037-1046.

Kılıç GB, Kuleasan H, Eralp I, Karahan AG (2009). Manufacture of Turkish Beyaz cheese added with probiotic strains. LWT- Food Sci Technol. 42:1003-1008.

Koburger JA, Marth EH (1984). Yeast and Moulds. In: Marvin L.Speck (Editor), Compendium of Methods for the Examination of Foods A.P.H.A., Washington D.C. pp. 197-202.

Laleye LC, Sımard RE, Lee BH, Holley RA, Gıroux RN (1987). Involvement of heterofementative Lactobacilli in development of open texture in Cheddar cheeses. J. Food Prot. 50(12):1009-1012.

Madureira AR, Soares JC, Pintado ME, Gomes AMP, Freitas AC, Malcata FX (2008). Sweet whey cheese matrices inoculated with the probiotic strain Lactobacillus paracasei LAFTI $^{\circledR}$ L26. Dairy Sci Technol 88: 649-665.

Martensson O, Öste R, Holst O (2002). The effect of yoghurt culture on the survival of Probiotic bacteri in oat-based, non-dairy products. Food Res. Int. 35:775-784.

Mattila-Sandholm T, Myllarinen P, Crittenden R, Mogensen G, Fonden $R$, Saarela $M$ (2002). Technological challenges for future probiotic foods. Int. Dairy J. 12:173-182.

Montville TJ, Matthews KR (2005). Food Microbiology: An introduction ASM Press, Washington, D.C.
Nikolaou E, Tzanetakis N, Litopoulou-Tzanetaki E, Robınson RK (2002). Changes in the microbiological and chemical characteristics of an artisanal, low-fat cheese made from raw ovine milk during ripening. Int. J. Dairy Technol. 55(1):12-17.

Özer B, Kirmacı HA, Şenel E, Atamer M, Hayaloğlu A (2009). Improving the viability of Bifidobacterium bifidum $B B-12$ and Lactobacillus acidophilus $L A-5$ in white-brined cheese by microencapsulation. Int. Dairy J. 19:22-29.

Phillips M, Kailasapathy K, Tran L (2006). Viability of commercial probiotic cultures ( $L$. acidophilus, Bifidobacterium sp., L. casei, $L$. paracasei and L. rhamnosus) in cheddar cheese. Int. J. Food Microbiol. 108(2):276-280.

Pitino I, Randazzo CL, Cross KL, Parker ML, Bisignano C, Wickham MSJ, Mandalari G, Caggia C (2012). Survival of Lactobacillus rhamnosus strains inoculated in cheese matrix during simulated human digestion. Food Microbiol. 31:57-63.

Rodrigues D, Rocha-Santos TAP, Gomes AM, Goodfellow BJ, Freitas AC (2012). Lipolysis in probiotic and synbiotic cheese: The influence of probiotic bacteria, prebiotic compounds and ripening time on free fatty acid profiles. Food Chem.131:1414-1421.

Ross RP, Fitzgerald G, Collins K, Stanton C (2002). Cheese delivering biocultures-probiotic cheese. Aust. J. Dairy Technol. 57:71-78.

Ross R, Fitzgerald G, Collins JK, Sullivan GC, Stanton C (2005). Process of manufacture of probiotic cheese. Enterprise Ireland and Teagasc, The Agriculture and Food Development Authority, Assignee. US Pat. No. 6872411. Accessed July 20, 2011. http://www.freepatentsonline.com/6872411.html.

Roy D, Mainville I, Mondou F (1998). Selective enumeration and survival of Bifidobacteria in fresh cheese. Int. Dairy J. 7:785-793.

Songisepp E, Kullisaar T, Hutt P, Elias P, Brilene T, Zilmer M, Mikelsaar $M$ (2004). A new probiotic cheese with antioxidative and antimicrobial activity. J. Dairy Sci. 87:2017-2023.

Songisepp E, Rätsep M, Shkut E, Kõljalg S, Truusalu K, Stsepetova J, Smidt I, Hütt P, Kolk H, Zagura M, Mikelsaar M (2012). Safety of a probiotic cheese containing Lactobacillus plantarum Tensia according to a variety of health indices in different age groups. J. Dairy Sci. 95:5495-5509.

Sousa MJ, Malcata FX (1996). Influence of pasteurization of milk and addition of starter cultures on protein breakdown in ovine cheese manufactured with extras from Flavor wears of Cynara carunculous. Food Chem. 57(4):549-556.

Souza CHB, Saad SMI (2009). Viability of Lactobacillus acidophilus La5 added solely or in co-culture with a yoghurt starter culture and implications on physico-chemical and related properties of Minas fresh cheese during storage. LWT- Food Sci Technol. 42:633-640.

Talwalkar A, Kailasapathy K (2004). Comparison of selective and differential media for the accurate enumeration of strains of Lactobacillus acidophilus, Bifidobacterium spp. and Lactobacillus casei complex from commercial yoghurts. Int. Dairy J. 14:143-149.

Tharmaraj N, Shah NP (2004). Survival of Lactobacillus acidophilus, Lactobacillus paracasei subsp. paracasei, Lactobacillus rhamnosus, Bifidobacterium animalis and Propionibacterium in cheese-based dips and the suitability of dips as effective carriers of probiotic bacteria. Int. Dairy J. 14:1055-1066.

TS 591 (1995). Beyaz Peynir, The Institute of Turkish Standards, Ankara, Türkiye.

Vinderola CG, Prosello W, Ghilberto D, Reinheimer JA (2000). Viability of probiotic (Bifidobacterium, Lactobacillus acidophilus and Lactobacillus case I) and nonprobiotic microflora in Argentinian Fresco cheese. J. Dairy Sci. 83:1905-1911.

Vinderola CG, Reinheimer JA (2003). Lactic acid starters and probiotic bacteria: A comparative "in vitro" study of probiotic characteristics and biological barrier resistance. Food Res. Int. 36:895-904.

Yıldız N, Bircan H, (1994). Araştırma ve deneme metodları. Atatürk Ünv. Ziraat Fak., Yay. No: 305, IV. Baskı, Erzurum. 